\title{
MAJELIS ULAMA INDONESIA (MUI); STUDI ATAS PENGGUNAAN METODOLOGI QIYAS SEBAGAI UPAYA PENETAPAN HUKUM ISLAM DI INDONESIA
}

\author{
${ }^{1} \mathrm{NASRULLAH}$ \\ ${ }^{1}$ STAI Auliaurrasyidin Tembilahan \\ Nasrullah.arul73@gmail.com
}

\begin{abstract}
Abstrak
MUI is one of the competent organizations in seeking Islamic legal solutions to legal events occurring in the country. In implementing the function of providing legal fatwa, MUI uses a set of methodologies before its solution in the form of a fatwa. Qiyas is one method that serves as an extension of laws that have not existed, or irrelevant to use in the Indonesian context. This paper provides an overview of the use of qiyas methodology by MUI. With the qualitative method, this research can be seen the confusion of legal decision due to inconsistency of qiyas use. This is not because of the unmanaged methodology or the quality of the individual in operation, but more because of the weakness of courage in the business aspect.
\end{abstract}

Katakunci: MUI, qiyas, hukum islam

PENDAHULUAN

Keputusan hukum yang ditetapkan melalui ijtihad adalah cerminan dari masalah yang berisifat lokal dan temporal. Artinya, pencarian/penggalian atas satu keputusan hukum belum akan dilakukan selama tidak ada kepentingan, masalah, atau peristiwa hukum yang menghendaki untuk diberikan pembenaranpembenaran atas nama hukum, pada masa dan atau tempat tertentu. Pembenaran (legitimasi) hukum tersebut diproduksi berdasarkan norma-norma yang diakui, seperti budaya, sosial, dan agama.

Tradisi penetapan hukum yang berlandaskan shari'at agama Islam dilakukan dalam disiplin ilmu Fiqh. Disiplin ini menyediakan kaidahkaidah yang dinamis dan elastis guna mengakomodir permasalahan dalam berbagai setting tempat dan waktu, yang terhimpun dalam cabang ilmu ushul al-figh (legal theory) dan al-qawaid al-fiqhiyyah (legal maxim).Ushul al-Fiqh sebagai sebuah ilmu, berisi metodologimetodologi perumusan dan 
Nasrullah; Majelis Ulama Indonesia (MUI); Studi Atas Penggunaan Metodologi Qiyas sebagai Upaya Penetapan Hukum Islam Di Indonesia

penetapan hukum yang beroperasi dan terkait erat dengan teks-teks shari'at, sedangkan al-qawa'id alFiqhiyyah menyediakan kaidahkaidah penalaran induktif yang dioperasikan untuk menghasilkan hukum dari keputusan-keputusan yang telah ada (yurisprudensi), setelah ditemukan kaidah-kaidah umum dari kodifikasi-kodifikasi putusan hukum tersebut.Fungsi praktis dari kedua cabang ilmu fiqh ini adalah untuk menyediakan perangkat pencarian dan penetapan hukum atas kasus-kasus baru yang belum terjadi pada masa lalu atau belum pernah ada ketetapannya. Di samping itu, keduanya juga menjadi alat uji atas keputusan yang telah dan validasi atas keputusan yang sedang dan akan- dibuat (baca: epistemologi).

Indonesia -sebagai tempat produksi hukum Islam- memiliki ragam segmen sosial, yang terdiri dari beragam suku, budaya, ras, bahasa, agama dan kepercayaan. Dalam hal agama, Islam bahkan bukanlah yang pertama. la telah didahului oleh tradisi keberagamaan Hindu-Budha, dan kepercayaankepercayaan. Untuk memproduksi sebuah hukum yang berdasarkan syari'at Islam, setidaknya, hendaklah tidak bersinggungan secara konfrontatif terhadap berbagai keragaman tersebut. Dengan kata lain, hukum yang diproduksi -untuk kemudian diumumkan dalam bentuk fatwa- memiliki sifat toleran.Untuk kepentingan tersebut, diperlukan seperangkat metodologi yang mapan dan akomodatif terhadap keragaman tempat dan waktu di mana hukum diproduksi.Tradisi pemikiran hukum Islam sesungguhnya telah memiliki perangkat metodologi ijtihad yang canggih dalam menghadapi setiap permasalah pada berbagai zaman dan tempat, diantaranya adalah Qiyas.

Pengoperasian motodologi qiyas dalam tradisi pemikiran hukum Islam harus dilakukan oleh orangorang yang memiliki kualitas tertentu yang dikenal dengan sebutan Mujtahid. Syarat yang ditetapkan oleh para Yuris Muslim -dalam tingkatnya yang tertinggi- sangat ketat, sehingga disinyalir tidak banyak orang yang memilikinya pada setiap zaman.Beberapa solusi dalam pemenuhan syarat tersebut kemudian diajukan oleh beberapa ulama tradisional, agar solusi hukum terus berlanjut sementara tidak terpenuhinya syarat mujtahid secara utuh. Dewasa ini di Indonesia, para ahli hukum beranggapan bahwa ijtihad kolektif adalah langkah yang paling strategis untuk kepentingan tersebut. MUI (Majelis Ulama Indonesia) adalah salah satu lembaga yang melakukan ijtihad secara kolektif, untuk memberikan putusan-putusan hukum Islam di Indonesia.

Penelitian ini secara khusus akan membicarakan tentang MUI dalam hal menggunakan qiyas sebagai metodologi menggali hukum yang solutif bagi peristiwa-peristiwa hukum yang terjadi di Indonesia. 
Al-Fikra: Jurnal IImiah Keislaman, Vol. 16, No. 2, Juli - Desember, 2017 (332 353)

\section{A. Metodologi Qiyas}

Istilah Qiyas biasa digunakan dalam beberapa disiplin kajian keislaman yang berbeda, di antaranya hukum Islam, bahasa, kalam/teologi, dan logika/filsafat. Dalam kajian hukum Islam, qiyas ditempatkan pada posisi keempat dari urutan dalil hukum, al-Qur'an, sunnah, ljma' dan Qiyas. Qiyas lahir paling belakang, ia dianggap sebagai prinsip, dasar atau sumber hukum yang keempat, seperti sumber-sumber lainnya. Sebenarnya qiyas adalah salah satu cara ijtihad dan bukan sebagai sumber hukum seperti yang digambarkan pada keempat perangkat teori hukum di atas. Alasannya adalah ia bukan hujjah (otoritas) dan bukan pula sumber yang berdiri sendiri. la merupakan proses ijtihad yang sistematis untuk mengungkap ketetapan hukum. la sepenuhnya bergantung pada sumber hukum yang lain, baik al-Qur'an maupun sunnah. Terkadang ia didasarkan pada ljma', yang juga mencari dukungan pada kedua sumber tersebut. Dengan demikian semua sumber tersebut saling terkait dan pada dasarnya merujuk pada satu sumber, yaitu al-Qur'an. Sedangkan fungsi qiyas dalam ushul al-fiqh untuk memperluas hukum yang secara tekstual tidak terdapat dalam al-Qur'an dan sunnah. Karena tidak semua persoalan yang terjadi ada penjelasannya secara tekstual di dalam al- Qur'an dan sunnah.

Qiyas, dalam disiplin bahasa Arab, ditempatkan pada posisi ketiga dalam deretan urutan dalil dalam cabang ilmu ini, yaitu al-sama' atau al-riwayah, ijma', dan qiyas. Fungsi qiyas dalam hal ini untuk memperluas kalam Arab dengan cara mengqiyaskan pada pola bahasa yang ada. Ibn Anbari (w. 557 $\mathrm{H})$ mendefinisikan qiyas sebagai "membawa (haml) far"' kepada asl karena ada 'illat dan memberlakukan hukm ashl kepada cabang tersebut. (Kamaluddin, 1987). Dengan kata lain ketetapan hukum bagi kasus cabang (far) didasarkan pada ketetapan hukum kasus pokok (ashl) karena ada sifat yang menghubungkan (washf jami) antara keduanya. Definisi Ibn Anbari ini terkesan mirip dengan definisi yang umum dalam ilmu Hukum Islam, seperti yang diungkapkan alal-Amidi, dengan mengutip pendapat Abu Husain al-Bashri, mengemukakan definisi qiyas sebagai "penerapan hukum ashl kepada far' karena ada kesamaan 'illat antara keduanya" (Saifuddin, 1996)

Walaupun secara teknis tidak sama persis, kemiripan qiyasdalam ilmu logika juga terlihat jelas dengan pandangan dua disiplin di atas. Dalam ilmu logika, yang merupakan salah satu cabang filsafat, qiyas dipahami sebagai "menetapkan sesuatu serupa dengan sesuatu yang lain" (Ahmad). Dalam ruang yang lebih teknis, ia beroperasi pada penetapan terhadap sesuatu yang inderawi, yang diperoleh dari dua premis. Pada setiap premis tersebut harus ada petunjuk yang sama, 
Nasrullah; Majelis Ulama Indonesia (MUI); Studi Atas Penggunaan Metodologi Qiyas sebagai Upaya Penetapan Hukum Islam Di Indonesia

sehingga dapat ditarik hukum afirmatif ataupun negatif. Pembuktian yang meyakinkah hanya dapat diperoleh dengan cara membuat penalaran berdasarkan qiyas yang akurat (Muhammad, 2007)

Al-Syafi'l membagi qiyas menjadi dua macam. Pertama, qiyas yang tingkat kemiripan antara kasus cabang dengan kasus asal sangat identik dalam esensinya. Kedua, qiyas yang memiliki keserupaan dengan beberapa cabang. Untuk yang disebut terakhir ini yang akan dijadikan patokan adalah yang paling banyak tingkat kemiripannya. Pembagian seperti ini memperlihatkan bahwaia berusaha sedapat mungkin untuk menjaga konsistensi dalam persoalan qiyas ini.

Unsur utama pembentuk qiyas dalam ushul al-fiqhatau struktur pembentuknya ada empat, yaitu, Hukumasal, cabang(far), asal(ashl) dan'illat. Mana kala membahas struktur qiyas dalam ushulal-fiqh ini, hukum asal tidak dibahas secara khusus, cukup disertakan dengan pembahasan ketiga unsur lainnya, karena tidak terlalu signifikan.

\section{Kasus Asal}

Kasus asal merupakan salah satu dari empat unsur pembentuk qiyas. Terjadi perbedaan pendapat ulama tentang definisi kasusasal. Menurut para teolog, ashl berarti nash. Misalnya,ayat al-Qur'an yang melarang minuman khamr atau hadith yang melarangtukar menukar gandum dengan ukuran berat yang tidak sama, merupakan kasus asal (ashl). Al-Syaukani mendefinisikan ashl sebagai nash yang menunjukkan penentuan ketetapan hukum dalam objek kesepakatan. Pendapat ini dipegang oleh Qadi Abu Bakral-Baqilani dan Mu'tazilah. Alasannya adalah karena nash menjadi sandaran bagi yang lain dan yanglainmenyandarpadanash, karena itu nash disebut ashl (Muhammad, 1986). Pendapat lainmengatakan kasus asal berarti ketetapan hukum yang ditunjuk oleh nash. Seperti tidak bolehnya minum khamr dan larangan tukar-menukar jenis barang yang sama dengan ukuran yang tidak sama, yang ditunjukkan oleh nash masingmasing. Pendapat ini dipegang oleh Abu Husainal-Bashridan Fakhruddinal-Razi. Untuk mendukung pandangan ini ditegaskan bahwa ashl adalah sesuatu di mana sesuatu yang lain bergantung kepadanya, dan pengetahuan tentang hal tersebut sangat penting untuk mengetahui yang lainnya. Sifat seperti ini dapat ditemukan dalam hukum yang ditunjuk oleh nash, seperti larangan minum khamr di atas. Karena itu ia harus disebut ashl.

Menurut al-Amidi perbedaan pendapat seputar masalah ini hanyalah perdebatan soal kata-kata (khilaflafzi). Sesungguhnya, hal itu sangat terkait dengan makna kata ash/ itu sendiri. Ash/ berarti sesuatu yang menjadi landasan bagi yang lain. Karena itu, Ketetapan hukum 
Al-Fikra: Jurnal IImiah Keislaman, Vol. 16, No. 2, Juli - Desember, 2017 (332 353)

dapat menjadi ashl, karena hukum dalam kasus cabang didasarkan padanya. Jika hukum merupakan ashl dalam kasus pelarangan minum khamr, maka nash yang dengannya hukum diketahui merupakan ashl bagi ashl yang lain (ketetapan hukum). Atas dasar ini, dengan cara apapun hukum tentang minum khamr diketahui, baik melalui ljma' atau lainnya, ia dapat menjadi ashl (Saifuddin, 2003). Lebih jauh al-Amidi berpendapat bahwa objek hukum lebih tepat dianggap ashl, Karena baik ketetapan hukum maupun nash menuntut keberadaannya, namun tidak sebaliknya, karena objek tidak selalu memerlukan nash atau hukum (Saifuddin, 2003).

\section{Kasus Cabang}

Kehidupan selalu dinamis, kondisi selalu berubah, situasi bervariasi dan masalah berubah sejalan dengan perubahan sosial. Perintah-perintah tekstual yang ada dalam al-Qur'an atau sunnah secara teknis dikenal dengan nushush, bentuk tunggalnya nash. Keputusan hukum yang didasarkan pada kesepakatan ummat Islam masalalu, yang juga merupakan sumber hukum otoritatif yang nilainya sama dengan nash, tidaklah cukup untuk menjawab masalah-masalah dan perubahanperubahan yang muncul dalam masyarakat yang selalu berubah. Masalah-masalah kehidupan yang selalu berubah sesungguhnya tak terbatas, sedangkan hukum-hukum tekstual tetap dan terbatas jumlahnya. Adalah tidak mungkin menyelesaikan yang tidak terbatas oleh yang terbatas (abu, 1979). Karena itu, penggunaan ra'y dan qiyas dimaksudkan untuk mencari jawaban bagi masalah- masalah yang tidak diungkap oleh hukumhukum tekstual tersebut. Kasuskasus, situasi dan masalahmasalah baru yang tidak dijawab secara langsung oleh hukum nas secara teknis disebut far' (cabang) atau maqis (kasus yang diungkap melalui qiyas). Adalah sulit untuk melacak asal-usul far' atau maqis dalam literatur hukum klasik. Tidak ditemukan kata far'yang digunakan Al-Shafi'l dalam pengertian kasus baru yang selaras dengan kasus yang diungkap oleh hukum nash. Untuk kasus yang serupa dengan kasus asal ia menggunakan kata shay' (sesuatu atau objek) (AlSyafi'l, 1921). Tentu saja ia menggunakan istilah maqis'alaih (kasusasal). Kemungkinan besar ia memahami dan menyadari penggunaan istilah maqis (kasuscabang). Namun Abu Bakaral-Jashshas (w. $270 \mathrm{H}$ ) sering menggunakan istilah far' untuk arti kasus cabang (Abu, 1979). Ini menunjukkan bahwa istilah far' telah digunakan oleh para ahli figh pada abad ke-3 dan ke-4 Hijrah. Tetapi tidak diketahui dengan pasti siapa orang pertama yang menggunakan istilah ini.

Definisi far', seperti juga definisi ashl, diperdebatkan oleh ahli fiqh. Mereka yang berpendapat 
Nasrullah; Majelis Ulama Indonesia (MUI); Studi Atas Penggunaan Metodologi Qiyas sebagai Upaya Penetapan Hukum Islam Di Indonesia

bahwa hukum kasus asal disebut ashl menegaskan bahwa hukum kasus cabang adalah far'. Misalnya jika hukum minum khamr disebut asl, hukum minum nabidz (minuman yang terbuat dari kurma) disebut far'. Kelompok lain mengatakan bahwa objek (mahall) adalah asl dan far', dan bukan hukum.

Dalam contoh diatas, nabidz adalah far' dan bukan hukum tentangnya. Al-Amidi berpendapat lebih baik menyebut hukum turunan tentang objek dengan far' dan objeknya sendiri dengan asl. Lebih baik menyebut khamr dengan asl ketimbang menyebut nabidz dengan far', karena khamr adalah kasus asal. Sebaliknya nabidz adalah objek asal yang berlaku baginya hukum turunan, dan bukan hukum turunan itu sendiri (Saifuddin, 2003)

Al-Bashri memberikan definisi far' menurut fuqaha'. Para teolog member definisi tentang far' sebagai ketetapan hukum yang harus ditetapkan melalui sebabakibat, seperti keburukan melakukan perbuatan zina. Fuqaha' mendefinisikan far' sebagai kasu satau objek yang hukumnya dicari melalu qiyas. Far'juga didefinisikan sebagai kasus yang hukumnya diperluas dari kasus lain, atau objek yang hukumnya diketahui ditingkat sekunder. la disebut far' karena ketetapan hukumnya diambil dari hukum kasuslain. Tetapi al-Basri sendiri lebih menyukai pendapat para teolog yang menganggap ketetapan hukum atau hukum turunan sebaga ifar', dan bukan objeknya itu sendiri seperti diakui oleh fuqaha' (Abu, 1982)

Pada abad-abad kemudian, definisi baru tentang as/ dan far' muncul sebagai akibat kontroversi masalah sebelumnya. Fuqaha' menyebut titik kesepakatan (mahallal-wifaq) dengan ashl dan titik perbedaan (mahall al-khilaf) denganfar' (Muhammad al Syaukani, tt)

Namun demikian, tetap tidak jelas apakah objek benar-benar far' atau hukum tentangnya. Titik kesepakatan (mahallal-ittifaq) berarti objek atau kasus yang tidak diketahui atau diperdebatkan. Ini menunjukkan bahwa objek adalah far' dan bukan hukum tentangnya.

\section{3.'Illat}

Unsur pembentuk qiyas berikutnya adalah 'illat. AlBazdawidanal-Syarakhsi menyebut 'illat dengan unsur esensial qiyas (ruknal-qiyas). Dengan member judul bab "Fashlfial-Rukn" atau "Babal-Rukn" (bab tentang unsur esensial), yang mereka maksudkan mungkin adalah bahwa illat itu sendiri adalah qiyas, sedangkan unsur-unsur lain berperan sebagai syarat-syarat untuk menentukan ketetapan hukum. Al-Bazdawi mengatakan unsure yang mendasar (ruknal-qiyas) adalah kualitas yang ditunjuk sebagai penanda bagi ketetapan hukum nash, di antara kualitas-kualitas yang dikandung oleh nas, danyang menjadi dasar bagi ketetapan hukum tersebut 
Al-Fikra: Jurnal IImiah Keislaman, Vol. 16, No. 2, Juli - Desember, 2017 (332 353)

berlaku bagi kasus cabang karena adanya kualitas yang sama didalamnya (Abu BakaralSharakhsi, 1954). Ketika Sharakhsi menjelaskan hal ini, ia melihat bahwa unsure mendasar (rukn) sesuatu itu adalah dasar bagi tegaknya sesuatu dan qiyas dibangun di atas kualitas ini (yakni, 'illat dan sebab) (Abu BakaralSharakhsi, 1954)

Secara literal 'illat berarti aksiden ('aridh) yang dengannya kualitas suatu objek berubah dari suatu kondisi kekondisi lain ketika ia diterapkan, seperti perubahan dari sehat ke sakit dan dari kuat ke lemah. Dengan katalain, 'illat merujuk pada sebab perubahan pada kondisi sesuatu. Karena itu aksiden ('aridh) disebut 'illat. Pendapat lain menegaskan bahwa 'illat berasal dari kata 'alal yang berarti minum air kedua kalinya yang dilakukan oleh binatang setelah sebelumnya ia minum. Jelasnya, 'illat berarti minum air berulang-ulang. Pandangan berikutnya menyatakan bahwa illat adalah sesuatu yang mempengaruhi sesuatu yang lain, apakah yang dipengaruhi itu kualitas atau esensi dan apakah ia mempengaruhi perbuatan atau diamnya sesuatu. Misalnya, sifat memabukkan merupakan 'illat datangnya hukum haram bagi khamar. Penyakit disebut 'illat karena ia mempengaruhi kesehatan seseorang yang menjadikannya lemah dan menghalangi seseorang melakukan berbagaikegiatan.
Berikut ini akan diterapkan makna-mana 'illat di atas pada definisi 'illat yang diterapkan dalam konteks hukum. Menurut makna yang pertama, kualitas yang mempengaruhi ketetapan hukum disebut 'illat, karena kondisi hukum tekstual berubah olehnya dari yang khusus keumum. Sebelum menentukan 'illat, ketetapan hukum terbatas hanya pada kasus yang disebutkan dalam nash. Tetapi setelah ditemukan kualitas yang mempengaruhi ini, ketetapan hukum yang terkandung dalam nash secara eksternal berubah dari yang khusus ke umum. Sekarang ketetapan hukum yang sama akan berlaku pada kasus lain jika 'illat yang sama ditemukan pada kasus lain itu. Menurut makna yang kedua, kualitas ini disebut 'illat karena ketetapan hukum ditentukan secara eksternal oleh makna ini, dan ketetapan hukum berulang dengan perulangan kualitasini. Karena seorang ahli hukum memikirkan secara berulang-ulang masalah yang berkaitan dengan qiyas, tindakan berpikirnya tentang alas anlogis penetapan hukum itu disebut 'illat. Menurut makna yang ketiga, kualitas ini disebut 'illat, ia berpengaruh dalam penetapan hukum apakah dalam kasus asal atau dalamk asus cabang (Muhammad, 1290)

Istilah 'illat secara teknis telah didefinisikan secara beragam seperti berikut : (1) Ideataudasar (ma'na) yang menuntut (yaqtadhi) atau menentukan ketetapan hukum; 
Nasrullah; Majelis Ulama Indonesia (MUI); Studi Atas Penggunaan Metodologi Qiyas sebagai Upaya Penetapan Hukum Islam Di Indonesia

(2) Sesuatu yang berperan sebagai tanda ('alam) bagi ketetapan hukum nas; (3) Sesuatu yang menunjukkan (mu'arrif) ketetapan hukum, yakni indikator (dali) bagi adanya perintah; (4) Sesuatu yang mempengaruhi (mu'atsir) dalam ketetapan hukum, yakni yang mempengaruhi adanya ketetapan hukum; (5) Sesuatu yang berperan sebagai motif (baits) bagi ketetapan hukum, bukan dengan jalan mewajibkan (ijab), tetapi sebagai kebijakan (hikmah) atau kebaikan umum (mashlahah) yang ditunjukkan oleh pemberi hukum ketika memberikan ketetapan hukum; (6) Sesuatu yang meniscayakan ketetapan hukum dengan sendirinya (mujiblial-hukm), pendapat ini dianut oleh Mu'tazilah; (7) Sesuatu yang mengharuskan ketetapan hukum, bukan dengan sendirinya, tetapi berdasarkan otoritas pemberi hukum; (8) Sesuatu yang meniscayakan ketetapan hukum, karena watak atau kebiasaannya. Pendapat ini dianut oleh Fakhruddinal-Razi.

\section{METODOLOGI}

Agar penelitian menjad
terarah, diperlukan sebuah metodologi penelitian. Penelian ini merupakan penelitian kepustakaan (Library Research), yang dioperasikan untuk mengeksplorasi dan mengenerallisasikan dokumendokumen yang berkenaan dengan teori-teori seputar qiyas, keputusankeputusan hukum oleh lembagalembaga hukum, yang berupa teori- teori, konsep-konsep, atau pernyataan-pernyataan tertulis para ahli berkenaan dengan masalah yang dibahas, yang disajikan dalam bentuk deskriptif, untuk kemudian dianalisis menggunakan metode berfikir deduktif dan induktif. Dengan demikian ia juga merupakan penelitian dengan metode penelitan kualitatif (Lexy, 1996).

\section{HASIL DAN PEMBAHASAN}

\subsection{MAJELIS INDONESIA (MUI) \\ ULAMA}

\subsubsection{Sekilas Sejarah MUI}

Majelis Ulama Indonesia (MUI) merupakan wadah musyawarah para ulama, zu'ama, dan cendikiawan muslim serta menjadi pengayom bagi seluruh muslim Indonesia (MUI, 2011). Sejarah resmi MUI mencatat bahwa organisasi ini lahir pada 26 Juli 1975 bertepatan dengan 7 Rajab $1395 \mathrm{H}$ (Majelis Ulama Indonesia, 2011), sebagai hasil dari pertemuan dan musyawarah ulama (Mohammad Atho Mudzhar, 1993) yang datang dari berbagai penjuru Indonesia. Peserta yang dimaksud adalah wakil 26 orang wakil dari 26 Provinsi, 10 orang ulama yang merupakan unsur dari ormas-ormas Islam tingkat pusat, yaitu, NU, Muhammadiyah, Syarikat Islam, Perti. Al Washliyah, Math'laul Anwar, GUPPI, PTDI, DMI dan al Ittihadiyyah, 4 orang ulama dari Dinas Rohani Islam, AD, AU, AL dan POLRI serta 13 orang tokoh/cendekiawan yang merupakan tokoh perorangan. 53 orang peserta 
Al-Fikra: Jurnal IImiah Keislaman, Vol. 16, No. 2, Juli - Desember, 2017 (332 353)

tersebut, di akhir Muktamar menandatangai sebuah deklarasi yang dikenal dengan "Piagam Berdirinya MUl" (Muhammad atho, 1993)

Berdirinya MUI tidak serta merta dipahami sebagai langkah maju eksistensi Islam di Indonesia. Sebagian masyarakat muslim bahkan tetap mencurigai MUI sebagai alat bagi kepentingan politik dan kekuasaan, meskipun posisi MUI bukan merupakan lembaga pemerintah. Setidaknya ada tiga peristiwa penting sebelum berdirinya MUI, yang menjadi indikator penting dugaan unindependensi MUI dalam hubungannya dengan pemerintah; pertama, berhubungan dengan kemunduran politik umat Islam Indonesia yang kalah pada Pemilu 1971, di mana setahun sebelumnya (1970), gagasan pendirian majelis ulama telah dilontarkan saat lokakarya Pusat Dakwah Islam. Gagasan ini kemudian diyakini sebagai strategi pemerintah untuk memecahkan perhatian kaum Muslimin dan campur tangan pemerintah terhadap hubungan ulama dengan masyarakat muslim. Hal ini lebih nyata terlihat pada lokakarya 1974, atas saran dan persetujuan presiden, agar segara memulai dengan membentuk Majelis Ulama tingkat daerah. Pembentukan tersebut berjalan cepat karena keterlibatan pemerinatah. Semua perwakilan majelis ulama yang dibentuk pemerintah inilah yang kemudian menjadi anggota Muktamar yang ikut menandatangani piagam pendirian MUI.

Kedua, tekanan yang dilakukan pemerintah agar partai Islam menanggalkan atribut Islam dan mendesakkan fusi ke dalam satu partai berdasarkan kesamaan orientasi; Nasionalis, Protestan, dan Katolik digabung dalam PDI, sedangkan Partai-Partai Islam kontestan pemilu 1971 digabung dalam PPP. Kenyataan ini adalah bentuk nyata pemerintah untuk membatasi gerakan Umat Islam, yang dalam hubungannya dengan pembentukan MUI adalah paradox.

Ketiga, peristiwa besar tentang rancangan UU Perkawinan yang menimbulkan perlawanan besar dari masyarakat yang beranggapan bahwa Rancangan tersebut adalah upaya sekularisasi dan pencideraan terhadap Hukum Islam. Reaksi tersebut kemudian ditanggapi serius oleh pemerintah dan bersedia merubah beberapa pasal yang menimbulkan gejolak. Pada kasus ini, hubungan dengan terbentuknya MUI, setidaknya dipahami sebagai upaya pemerintah untuk menetralisir pandangan masyarakat yang mayoritas Muslim dalam rangka menghadapi Pemilu yang dijadwalkan 1976 (Muhammad atho, 1993).

Ketiga peristiwa sebagaimana di atas, pada gilirannya berpengaruh pada penerimaan masyarakat Indonesia terhadap fatwa atau nasehat keagamaan oleh MUI, bahkan hingga sekarang. Seperti tanggapan Hizbut Tahrir Indonesia 
Nasrullah; Majelis Ulama Indonesia (MUI); Studi Atas Penggunaan Metodologi Qiyas sebagai Upaya Penetapan Hukum Islam Di Indonesia

terhadap Fatwa MUI tentang menggunakan hak pilih dalam pemilihan Umum, Tanggapan HTI terdiri dari 6 point yang pada dasarnya mewakili ideologi/ keyakinan garis perjuangan organisasi ini. Namun yang menjadi sorotan di sini adalah tanggapan terhadap hal teknis dalam penetapan hukum, di mana HTI menganggap hukum 'wajib-haram' oleh MUI tidak dapat diterima bila tidak ditetepkan bersamanya kulifikasi wajib kifa'ai/kolektif atau 'aini/perorangan.; (http://hizbuttahrir.or.id/2009/01/29/tanggapanhizbut-tahrir-indonesia-terhadapfatwa-mui-tentang-golput/, 2015). Tentang hal ini, komnas HAM bahkan memberikan tanggapan yang lebih keras. ( http://www.hukumonline.com/berita/b aca/hol21080/komnas-ham-kecamfatwa-golput-haram, 2015) di mana MUI menetapkan bahwa memilih pemimpin yang beriman dan bertakwa, jujur (siddiq), terpercaya (amanah), aktif dan aspiratif (tabligh), mempunyai kemampuan (fathanah), dan memperjuangkan kepentingan umat Islam hukumnya adalah waiib, dan tidak memilih hukumnya haram. (Majelis Ulama Indonesia, 2011)

\subsubsection{Fatwa dalam MUI}

MUI memiliki beberapa fungsi, diantaranya adalah sebagai 'pemberi fatwa kepada Umat Islam dan Pemerintah, baik diminta maupun tidak diminta' (Majelis Ulama Indonesia, 2011). Sedangkan Usaha yang dilakukan berkenaan dengan fungsi pemberi fatwa ini dijelaskan dalam pasal 6 (3) "memberikan peringatan, nasehat dan fatwa mengenai masalah keagamaan dan kemasyarakatan kepada masyarakat dan pemerintah dengan bijak (hikmah) dan menyejukkan".

Ada tiga istilah yang digunakan dalam merespons permasalahan di dalam MUI, yaitu memberi peringatan, Nasehat dan fatwa. Namun pada prakteknya, setiap keputusan baik berupa jawaban dari pertanyaan, peringatan, nasehat atau fatwa, ditetapkan dengan sebutan fatwa. Dalam item keputusannya, semua bentuk respons hanya ditetapkan dengan dua diktum; yaitu menyebutkan substansi hukum yang difatwakan, dan jika dipandang perlu, diberikan rekomendasi dan/atau jalan keluar (Majelis Ulama Indonesia, 2011). Tidak ada klassifikasi khusus untuk fatwa terhadap masalah-masalah fiqhi-'amali, atau masalah I'tiqadi, serta 'aqli. Oleh karena itu, berdasarkan perspektif yang telah dibangun di bab sebelumnya, maka keputusan, fatwa, nasehat, usulan, atau rekomendasi MUI yang merupakan respons terhadap pemikiran/aliran-aliran, atau masalah-masalah l'tikad, harus diabaikan.

Terdapat perkembangan struktur dalam penetapan fatwa di MUI sejak 1999, yang berkenaan dengan masalah-masalah ekonomi, yang dalam rumusan kajian fiqh disebut dengan fiqh mu'amalah. 
Al-Fikra: Jurnal IImiah Keislaman, Vol. 16, No. 2, Juli - Desember, 2017 (332 353)

Struktur tersebut diberi nama Dewan Syari'ah Nasional Majelis Ulama Indonesia (DSN-MUI). Dalam hal memberikan keputusan hukum yang berkenaan dengan kegiatan ekonomi, perbankan dan keuangan, juga diberikan dalam bentuk fatwa.

Bentuk keputusan lain yang juga ditetapkan dengan mekanisme fatwa adalah penetapan fatwa halal yang diiringi dengan penerbitan sertifikat halal bagi perusahaan obat dan makanan yang meminta. Dalam hal ini, sepanjang berkenaan dengan perbuatan dan diduga melalui proses penalaran qiyas, dipertimbangkan sebagai data untuk mengidentifikasi bentuk penggunaan qiyas oleh MUI.

Dengan demikian diketahui bahwa fatwa MUI adalah segala pendapat final yang ditetapkan oleh Organisasi MUI melalui jalur-jalur organisatoris tertentu terhadap segala masalah yang dianggap perlu ditetapkan dengan sudut pandang ajaran Islam. Keumuman dan keluasan cakupan fatwa dalam organisasi ini tidak menghalangi kajian ini untuk mengidentifikasi dan menganalisis karakteristik metodologis penggunaan qiyas sebagai salah satu metode ijtihad MUI, karena system penalaran yang menjadi focus penelitian ini adalah penalaran hukum fiqh, maka pendapat yang dijadikan objek kajian berkenaan dengan masalah figh saja. Secara umum kajian fiqh dibagi berdasarkan tema-tema tertentu yang secara garis besar dibagi menjadi dua, yaitu Ibadah dan
Mu'amalah. Logika ini akan kita terapkan dalam pembahasan lanjutan dalam melihat qiyasdi MUI. Namun sebelumnya, perlu dipaparkan terlebih dulu prosedur penetapan Fatwa oleh MUI, untuk melihat adakah teori ijtihad tertentu yang diyakini dan kecenderungankecenderungan pemikiran hukumnya.

\subsubsection{Prosedur Penetapan Fatwa}

Dalam Pedoman dan Prosedur Penetapan Fatwa MUI, pasal ketentuan umum bab 2 pasal 7 disebutkan bahwa fatwa adalah "jawaban atau penjelasan Ulama mengenai masalah keagamaan dan berlaku umum" (Majelis Ulama Indonesia, 2011). Sedangkan fatwa yang dilakukan oleh MUI dijelaskan dalam pasal berikutnya (pasal 8) yaitu "fatwa MUI tentang suatu masalah keagamaan yang telah disetujui oleh anggota Komisi dalam rapat". Bagian pertama adalah teori umum tentang fatwa yang tidak hanya berlaku pada masalahmasalah fiqh-amali dengan menganalisis dalil-dalil shari'at yang zhanni, tetapi berkenaan dengan seluruh permasalahan yang perlu dan patut direspons dengan kaca mata Agama Islam. Sedangkan yang kedua berkenaan dengan fatwa yang secara teknis dilakukan oleh MUI, yang menyangkut prosedur dan metode penalaran serta teknis pengambilan keputusan.

Fatwa yang dilakukan MUI secara teori harus melewati serangkaian prosedur organisatoris 
Nasrullah; Majelis Ulama Indonesia (MUI); Studi Atas Penggunaan Metodologi Qiyas sebagai Upaya Penetapan Hukum Islam Di Indonesia

dan juga penalaran (ijtihad). Secara organisatoris, fatwa secara khusus menjadi tugas komisi fatwa. Namun pengumumannya terkadang dilakukan oleh komisi fatwa sendiri atau -dan bersama- MUI. Permasalahan yang dibicarakan dalam MUNAS umumnya langsung diumumkan melalui komisi $\mathrm{C}$ bidang Fatwa. DSN-MUI, sebagaimana telah disebutkan, sejak tahun 1999 dibentuk oleh MUI -secara khusus untuk mengamati masalah-masalah ekonomi, keuangan, dan perbankanmulai tahun 2000 juga memiliki kewenangan untuk menerbitkan fatwa, nasehat, peringatan, usulan, atau rekomendasi, terkait dengan bidang garapannya.

Permasalahan yang ditanggapi dan dicarikan keputusan hukumnya adalah segala persoalan yang dihadapi masyarakat, baik diajukan ke MUI atau tidak. Dalam hal ini MUI menjalankan fungsinya mewakili kepentingan umat Islam untuk mengawal segala peristiwa yang terjadi di Indonesia agar tidak bertentangan dengan shari'at Islam sebagai agama yang paling banyak dianut masyarakat. Sejak tahun 1975 hingga 2011 MUI telah menerbitkan 14 fatwa bidang Akidah dan Aliran keagamaan, 37 fatwa yang digolongkan bidang Ibadah, 86 fatwa dalam bidang lain selain aqidah dan ibadah (Himpunan Fatwa MUI, 2011). Beberapa fatwa yang disebutkan Mohammad Atho' Mudzhar tidak dimuat dalam buku Himpunan Fatwa tahun 1984 yang menjadi rujukannya, sebagian ada

dalam buku Himpunan Fatwa tahun 2011, seperti pemindahan Mayat, dan Bunga bank. Sedangkan fatwa tentang buku Amran Hambri yang dianggap controversial, tuntunan bersembahyang dalam kaset, olahraga tinju, dan Gerhana (bulan dan Matahari), tetap tidak ada dalam buku Himpunan Fatwa 2011 (Mohammad Atho Mudzhar, 1993). Sedangkan fatwa yang diterbitkan melalui DSN-MUI setidaknya terdapat 53 fatwa hingga tahun 2006 (Dewan Syari'ah Nasional MUI, 2006).

Sebelum mengumumkan pendirian finalnya, MUI terikat dengan prosedur penetapan keputusan hukum, yang tertuang dalam Pedoman dan Prosedur Penetapan Fatwa. Pedoman yang merupakan aturan pokok penalaran hukum/ijtihad MUI dihasilakan melalui ijtima' Ulama' Komisi Fatwa se-Indonesia tahun 2003. Langkahlangkah penalaran hukum/ijtihad MUI dibicaraan dalam bab 2 dan bab 3. Bab 2 mengenai dasar umum dan sifat fatwa terdiri dari 3 pasal, yaitu:

1. Penetapan fatwa didasarkan pada Al-Qur'an, Sunnah (hadis), ljma', dan Qiyas serta dalil lain yang mu'tabar.

2. Aktivitas penetapan fatwa dilakukan secara kolektif oleh suatu lembaga yang dinamakan Komisi Fatwa.

3. Penetapan fatwa bersifat
responsive, proaktif, dan
antisifatif. 
Al-Fikra: Jurnal IImiah Keislaman, Vol. 16, No. 2, Juli - Desember, 2017 (332 353)

Sedangkan bab 3 tentang metode penetapan fatwa berisi 5 pasal, yaitu:

1. Sebelum fatwa ditetapkan hendaklah ditinjau lebih dahulu pendapat para imam mazhab dan ulama yang mu'tabar tentang masalah yang akan difatwakan tersebut, secara seksama berikut dalil-dalilnya.

2. Masalah yang telah jelas hukumnya hendaklah disampaikan sebagaimana adanya.

3. Dalam masalah yang terjadi khilafiah di kalangan mazhab, maka,

a. Penetapan fatwa didasarkan pada hasil usaha penemuan titik temu di antara pendapatpendapat Ulama Mazhab melalui metode al-Jam'u wa al-taufiq; dan

b. Jika usaha penemuan titik temu tidak berhasil dilakukan, penetapan fatwa didasarkan pada hasil tarjih melalui metode muqaranah dengan menggunakan kaidah-kaidah Ushul Fiqh Muqaran.

4. Dalam masalah yang tidak ditemukan pendapat hukumnya di kalangan mazhab, penetapan fatwa didasarkan pada hasil ijtihad Jama'l (kolektif) melalui metode bayani, ta'lili (qiyasi, istihsani, ilhaqi), istishlahi, dan sadd al-zari'ah.

5. Penetapan Fatwa harus senantiasa memperhatikan kemaslahatan umum (mashalih

$$
\begin{aligned}
& \text { 'ammah) dan maqashid al- } \\
& \text { syari'ah. }
\end{aligned}
$$

Dasar penetapan fatwa MUI, sebagai mana disebutkan dalam bab II pasal 1 pedoman dan Prosedur Penetapan Fatwa adalah Al-Qur'an, Sunnah (Hadith), ljma', dan Qiyas serta dalil lain yang mu'tabar. Gambaran ini menetapkan alur ijtihad yang digunakan MUI sebelum mengumumkan keputusan hukumnya. Terhadap dua dalil pertama, komisi fatwa menjelaskan: "Ketentuan ayat ini merupakan kesepakatan dan keyakinan umat Islam bahwa setiap fatwa harus berdasarkan pada kedua sumber hukum yang telah disepakati tersebut. Fatwa yang bertentangan atau tidak didasarkan dengan keduanya dipandang tidak sah, bahkan dipandang sebagai tahakum dan perbuatan dusta atas nama Allah yang sangat dilarang agama."

ljma', diakui sebagai dalil hukum di bawah Al-Qur'an dan Sunnah. Artinya, ijma' hanya boleh terjadi bila tidak ada ketetapan dari keduanya. Namun otoritas Ijma' sangat kuat, bersifat absolut dan berlaku universal. Oleh karenanya, penerimaan terhadap ijma' adalah mutlak. Akibatnya, bila terdapat peristiwa yang tidak terdapat petunjuknya dari al-Qur'an dan alSunnah, dan terdapat satu pendapat yang diakui atau tidak dibantah oleh orang lain, maka tidak diperkenankan untuk melanjutkan ijtihad dengan metode-metode lain 
Nasrullah; Majelis Ulama Indonesia (MUI); Studi Atas Penggunaan Metodologi Qiyas sebagai Upaya Penetapan Hukum Islam Di Indonesia

dan fatwa hanya boleh diumumkan berdasarkan pendapat tersebut.

Khusus tentang Qiyas dan dalil-dalil lain setelah ljma', penggunaannya oleh MUI sebenarnya menempati posisi metodologis yang tidak serta merta dilakukan setelah istinbat dengan alQur'an, Sunnah, dan Ijma'. Ada metode lain yang menjembataninya, yaitu apa yang disebut dengan ljtihad Intiqa'l, yang diartikan sebagai memilih pendapat para ulama terdahulu setelah dikaji secara komprehenship. Pengkajian terhadap pendapat-pendapat para ulama, jika memungkinkan dilakukan dengan mekanisme al-jam' wa altaufiq. Yaitu sebuah usaha untuk menggabungkan dan mengharmoniskan pendapatpendapat yang berbeda. Namun bila tidak ditemukan keseragaman dan titik temu, maka dilakukan dengan mekanisme tarjih. Setelah sama sekali tidak ditemukan dalam keputusan yuris muslim terdahulu/yurisprudensi, atau tidak dapat diterima dalam konteks Indonesia, maka metode ijtihad yang independens dilakukukan dengan asas jama'l (kolektif).

\subsubsection{Qiyasdalam Bidang Ibadah}

1. Penerimaan MUI terhadap Qiyas dalam Bidang lbadah

MUI meyakini bahwa "Umat Islam Indonesia menganut paham ahlus sunnah wal jama'ah dan mayoritas bermazhab Syafi'i". Akomodasi atas pendirian masyarakat Indonesia dalam bermazhab ini, bisa dilihat dari pandangan mazhab-mazhab Sunni yang dijadikan dasar penetapan fatwa. Khusus dalam bidang ibadah, di mana terdapat hampir di semua lembar fatwa, disertakan pandangan mazhabmazhab tersebut. Meskipun pada sebagian keputusannya, MUI mendasarkan keputusan pada pandangan Zahiri, yang secara teoritis adalah mazhab yang tidak popular di kalangan sunni, dalam konteks "tertentu". Karena inilah, Mohammad Atho Mudzhar, dalam kajiannya menyimpulkan kecenderungan inkonsistensi metodologis dalam fatwa MUI (Mohammad Atho Mudzhar, 1993).

Bentuk lebih teknis dalam kajian Qiyas yang diterima oleh mayoritas yuris mazhab-mazhab Sunni adalah keberlakuan qiyas dalam masalah-masalah ibadah. MUI, sepanjang penyelidikan penulis, tidak memunculkan satupun kata qiyas dalam konsideran fatwanya. Namun demikian, beberapa petunjuk dapat digunakan untuk melihat keberlakuan qiyas dalam fatwa MUI bidang ibadah, dengan cara melakukan analisa terhadap dalil, alur penalaran pendapatpendapat yang dijadikan dasar, dan kaidah-kaidah fiqh/legal maxim yang digunakan, sebagaimana yang akan kita sajikan dalam sub di bawah ini.

2. Karakteristik Dalil 
Kata 'qiyas' tidak sering disebutkan dalam konsideran fatwa MUI. Demikian juga Dalil nash al-Qur'an, hadith, dan ijma' yang digunakan MUI dalam mencari 'illat (maslak al-illah) sebagai bentuk istinbath hukum melalui qiyas, juga tidak banyak muncul dalam fatwanya. Hal ini dikarenakan masalah yang direspons memang tidak selalu berkenaan dengan hukum yang layak dan harus ditetapkan berdasarkan qiyas, atau terdapat kecenderungan mendasarkan pada pendapat-pendapat tokohtokoh mazhab yang mungkin menggunakan qiyas dalam penalaran hukumnya, sehingga akan lebih mudah dan praktis demi kepentingan mendesak agar kepastian hukum segera diumumkan kepada masyarakat. Secara organisatoris hal ini tentu saja tidak bisa disimpulkan sebagai sebuah kelemahan metodologis, karena -pada dasarnya- ketetapan untuk mengkaji dan menggunakan pendapat mazhab-mazhab yang dianggap sesuai untuk dijadikan dasar penetapan hukum telah melewati kesepakatan organisatoris, yang berhak untuk diapresiasi oleh semua pihak. Namun di sisi lain, kajian ilmiah yang membaca secara objektif tentang mekanisme penetapan hukum satu lembaga/organisasi juga layak untuk dipertimbangkan sebagai sebuah kebenaran
(Mohammad Atho Mudzhar, 1993).

Di antara dalil Al-Qur'an yang menunjukkan penggunaan qiyas oleh MUI dalam bidang Ibadah adalah fatwa no. 1 tahun 2001 tentang Haji bagi Narapidana. Dalam fatwa ini, ayat yang digunakan sebagai dasar adalah Q.S. Al 'Imran: 97.

"kesanggupan melakukan perjalanan" merupakan syarat kewajiban ibadah haji. Sedangkan "kesanggupan" itu sendiri juga merupakan alasan hukum yang tampak dari nash. Alasan hukum ini disebut dengan illat.

Dalam kasus orang yang badannya terkurung seperti narapidana dan sebagainya, yang memiliki kesanggupan biaya, MUI memutuskan bahwa orang tersebut tidak memiliki istitha'ah yang berakibat pada tidak terpenuhinya syarat wajib haji. Pandangan ini sejalan dengan pendapat Imam Malik dan Mazhab Hanafi, yang memperluas jangkauan istitha'ah tidak hanya pada ongkos (zad) dan kendaraan (al-rahilah). Namun terdapat penggalan redaksi fatwa yang mengharuskan kita mengkaji penalaran metodologis lebih jauh, yaitu "ia wajib membiayai orang lain yang sudah menunaikan haji untuk menghajikannya".

Kewajiban di atas tampak kontradiktif dengan penetapan istitha'ah sebagai syarat, di mana 
Nasrullah; Majelis Ulama Indonesia (MUI); Studi Atas Penggunaan Metodologi Qiyas sebagai Upaya Penetapan Hukum Islam Di Indonesia

ketiadaan syarat mengakibatkan ketiadaan hukum, sebagaimana yang diyakini Imam Malik dan Hanafi. Adapun ibadah haji dilakukan oleh orang lain, maka ia adalah peristiwa hukum lain yang berbeda, yang merupakan varian dari masalah hukum tatkala seseorang tidak ada harapan lagi untuk menunaikan ibadah haji (seperti usia renta, atau mengidap penyakit akut yang tidak ada harapan sembuh), atau telah meninggal dunia.

Penetapan hukum bagi narapidana dengan mewajibkan ia membayar orang lain untuk melaksanakan hajinya memiliki setidaknya- tiga masalah metodologi. Pertama, bahwa permasalahan ini masih berkenaan dengan tahqiq/pengukuhan makna istitha'ah yang berarti zad dan rahilah, keduanya berbentuk harta. Dalam hal seseorang memiliki keduanya, maka ia telah memenuhi syarat istitha'ah dan telah datang kepadanya kewajiban haji. Halangan pelaksanaan kewajiban tersebut, diselesaikan dengan berbagai cara sesuai dengan keadaan yang ada, seperti bila mana halangannya tidak mampu berjalan karena tidak memiliki kaki, maka ia boleh mengajak orang lain yang mau mematuhinya -atau dengan membayar- untuk membantu pelaksanaan dengan tandu, kursi roda atau sebagainya; apa bila halangannya karena sakit, maka ia boleh menunda sampai sembuh. Artinya kewajiban melaksanakan sendiri tetap ada karena syarat telah terpenuhi. AlSyafi'l dan pengikutnya berada dalam posisi penalaran bentuk ini.

Kedua, kemampuan badan merupakan syarat istitha'ah. Apabila kemampuan harta (ongkos dan kendaraan) dan badan (sehat dan bebas) telah terpenuhi, maka telah datang kewajiban haji. Namun bila tidak terpenuhi, berakibat pada tidak adanya kewajiban. Dengan tidak adanya kewajiban haji, maka tidak akan datang kewajiban membayar orang lain untuk menggantikan pekerjaan yang ia sendiri tidak wajib mengerjakannya. Ketegasan Imam Malik yang menunjukkan konsistensi penalaran bentuk kedua ini juga dirujuk MUI dalam lampiran referensi yang digunakan, yaitu tatkala beliau berpendapat bahwa orang yang lumpuh (al-ma'dub) tidak wajib haji dan tidak wajib digantikan orang lain.

Ketiga, kasus narapidana bukan lagi masalah istitha'ah, namun ia berhubungan dengan orang yang sakit akut, tua, atau telah meninggal. Kasus ini, meskipun dipertimbangkan untuk mengisi makna istithaah, namun memiliki ashl tersendiri dalam hukum, yaitu hadith ibn 'abbas tentang seorang wanita dari Khath'am yang bertanya kepada 
Rasulullah SAW, apakah ia boleh menunaikan haji untuk bapaknya yang telah renta dan tidak mampu -bahkan- untuk duduk di kendaraan.

Sandaran (manath) 'illat yang dikukuhkan dalam kasus serupa ini adalah orang tua yang tidak mampu karena sifat tuanya yang permanen. Konteks permanen ini bisa diluaskan pada orang yang sakit akut, yang diduga tidak ada harapan sembuh. Sifat halangan yang permanen ini menegasikan perluasan hukum pada yang sifatnya temporal. Bahkan alSyafi'i -setelah menyitir ucapan 'Ali bin Abi Thalib kepada seorang jompo "jika anda mau, anda boleh membiayai orang lain untuk menghajikan anda"- menegaskan:

"jika orang tua tersebut membiayai orang lain untuk menghajikannya, kemudian diduga suatu ketika datang kondisi di mana ia mampu berkendara untuk berhaji, maka tidak diperkenankan orang lain menghajikannya, ia harus menunaikan sendiri. Apa bila ia meninggal sebelum sempat mengerjakannya, atau keadaan 'sanggup' tersebut berubah lagi menjadi tidak sanggup, maka ia wajib dihajikan atau mengutus mengirim orang lain untuk menghajikannya. Karena hajinya dianggap tunai dikerjakan oleh orang lain hanya setelah ia tidak ان لا يجد السبيل) menemukan 'jalan' ). Bila masih ada jalan, ia wajib menunaikan sendiri".

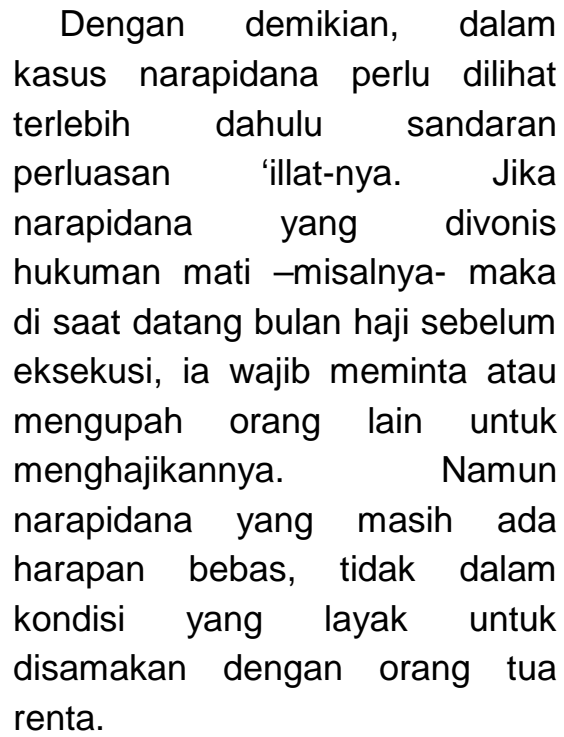

Fatwa MUI dalam kasus narapidana, berikut penjelasan dalil yang diajukan, tampak sekilas sebagai upaya menggabungkan pendapatpendapat yang berbeda dari mazhab-mazhab figh. Namun kemudian usaha ini menjadi aksi pencampur-adukan penalaran yang bahkan ditolak oleh seluruh yuris yang pendapatnya dijadikan dasar fatwa. Al-Syafi'i akan menerima redaksi fatwa point (a), yaitu: "orang yang sudah mempunyai biaya untuk menunaikan ibadah haji, tetapi kondisi badannya tidak memungkinkan untuk melaksanakan ibadah haji sendiri, baik karena sudah terlalu tua maupun karena suatu penyakit, dipandang telah memenuhi syarat istitha'ah. Karena itu, ia sudah berkewajiban haji ", namun alSyafi'i -juga Hambali- akan menolak ketetapan lanjutannya "orang tersebut tidak dibolehkan 
Nasrullah; Majelis Ulama Indonesia (MUI); Studi Atas Penggunaan Metodologi Qiyas sebagai Upaya Penetapan Hukum Islam Di Indonesia

melaksanakan haji sendiri tetapi ia wajib membiayai orang lain yang sudah menunaikan haji untuk menghajikannya", karena haji adalah ibadah personal yang hanya dapat digantikan dalam keadaan tertentu yang bersifat kasuistik dan pengecualian. Membawa kasus dengan menggunakan 'illat dari kasus pengecualian adalah qiyas yang fasid. Adapun Malik dan Hanafi akan langsung menolak kewajiban haji bagi yang tidak memenuhi syarat kemampuan harta dan badan.

Kasus di atas memperlihatkan karakteristik penggunaan qiyas yang tidak mandiri dan rentan kritik. Sedangkan dukungan penalaran yang pada dasarnya berseberangan satu sama lain memperlihatkan kecenderungan eklektis dalam metodologinya.

Bentuk lain yang mungkin dapat mempertegas pencarian terhadap karakteristik penggunaan dalil dalam memberlakukan penalaran qiyas dalam fatwa MUI adalah tentang zakat penghasilan dan jasa. Tentang penghasilan dan jasa, MUI menetapkan fatwa bahwa setiap penghasilan wajib dikenakan zakat. Fatwa tentang ini muncul dua kali, pertama pada tahun 1982 tentang intensifikasi pelaksanaan zakat. Pada point 1 berbunyi:

"Penghasilan dari jasa dapat dikenakan zakat apabila sampai nisab dan haup' (Majelis Ulama Indonesia, 2011).

Pada tahun 2003, secara khusus MUI memfatwakan tentang zakat penghasilan, yaitu Fatwa no.3 tahun 2003. Dalam fatwa ini disebutkan hukum 'wajib' secara tegas:

"semua bentuk penghasilan halal wajib dikeluarkan zakatnya dengan syarat telah mencapai nisab dalam satu tahun, yakni senilai emas 85 gram" (Majelis Ulama Indonesia, 2011).

Kewajiban zakat telah ma'lum diketahui dalam syari'at secara dharuri, tetapi tentang harta apa saja yang wajib dikenakan zakat, memerlukan upaya istidlal terhadap dalil dan istinbath hukum. Harta zakat yang diidentifikasi para fuqaha berdasarkan nash ataupun melalui berbagai metode penalaran terhimpun dalam beberapa jenis; perhiasan (emas dan perak), tanaman, buahbuahan dan biji-bijian, perniagaan, ternak, galian dan temuan. Adapun perluasan hukum kepada jenis harta lain, secara metodologis harus melewati serangkaian penalaran yang dianggap sah dalam teoriteori hukum Islam.

Dalil yang digunakan MUI dalam fatwa intensifikasi pelakasanaan zakat tahun 1982 M, setelah ayat dan hadith tentang kewajiban zakat, adalah beberapa hadith tentang jenis harta yang dizakatkan. Pertama, 
jenis buah-buahan dan biji-bijian, diiringi dengan pandangan tokohtokoh mazhab:

a. Imam Malik dan al-Syafi'i yang berpegang pada ijma' hasil tanaman tertentu dan bijibijian. Selain itu, hukum harus diperluas melalui qiyas dengan 'illat 'makanan pokok' atau sifat mengenyangkan ( ), dan tahan lama atau dapat disimpan.

b. Jumhur fuqaha' Maliki, Syafi'i, dan Hambali yang menyepakati terdapat sebagian jenis tanaman yang ada pada masa Rasulullah SAW namun tidak dikenakan zakat, yaitu sayur-sayuran dan buah-buahan.

Kedua, jenis ternak gembala. Dalam hal ini hanya diajukan satu hadith tentang tidak wajib zakat pada kepemilikan harta berupa budak dan binatang tunggangan (Majelis Ulama Indonesia, 2011).

Dari dalil-dalil yang diajukan, secara langsung dapat segera dipahami bahwa ketiga mazhab tersebut -walaupun berbeda dalam rinciannya- sepakat bahwa tidak semua harta jenis biji-bijian dan tumbuh-tumbuhan, serta ternak gembala, wajib dikenakan zakat. Oleh karena itu, fatwa tentang penghasilan dari jasa sebagai harta yang wajib zakat, terlihat tidak didukung oleh dalil yang diajukan atau -bahkanparadox.

Fatwa pada tahun 2003 tentang Zakat Penghasilan tampaknya tidak lagi menggunakan dasar-dasar hadith tentang jenis-jenis harta zakat, kecuali satu hadith tentang 'budak dan kuda tunggangan' yang disertakan dengan penjelasan Imam Nawawi yang menyebutkan bahwa sifat kedua harta tersebut adalah untuk dipakai bukan untuk dikembangkan. Dalil lebih diarahkan untuk memberikan muatan makna 'ghina' (kaya), yang dikuatkan dengan mengutip pandangan Yusuf al-Qardawi; "zakat hanya wajib pada harta yang sampai nishab, bebas dari hutang, dan merupakan kelebihan dari keperluan dasar. Ketentuan tersebut (berguna) agar nyata makna "kaya", yang karenanya zakat menjadi wajib" (Majelis Ulama Indonesia, 2011).

Penetapan kewajiban zakat dengan dasar makna ghina (kaya) berikut semua makna yang dicakupnya, merupakan pandangan yang cukup liberal, dan -khususnya dalam masalah zakat- biasa dilekatkan kepada ahli-ahli hukum kalangan Hanafi. Dan memang tidak sulit untuk menemukan pendapat ini dalam karya-karya standart Mazhab Hanafi, seperti bahwa "zakat hanya wajib bagi yang kaya" (Muhammad bin Ahmad, 1990) atau bahwa "memandang nisab saja tanpa memandang kaya-nya si pemilik harta tidak diperbolehkan" (Muhammad bin Abi Sahl). Meskipun demikian, bilamana menyangkut harta yang 
Nasrullah; Majelis Ulama Indonesia (MUI); Studi Atas Penggunaan Metodologi Qiyas sebagai Upaya Penetapan Hukum Islam Di Indonesia

wajib dikenakan zakat, mazhab Hanafi pun terikat sangat erat dengan dalil-dalil yang menunjukkan jenis zakat yang ditetapkan dalam nash. Akibatnya, mereka juga tidak mewajibkan seluruh harta dalam rincian keputusan fiqhnya.

\begin{tabular}{lcr}
\multicolumn{1}{r}{ Beberapa } & kasus & yang \\
dikemukakan & di & atas \\
memperlihatkan & \multicolumn{2}{c}{ karakteristik } \\
penggunaan & dalil & dalam \\
mengoperasikan & metodologi & qiyas \\
oleh MUl tidak cukup akurat.
\end{tabular}
Akibatnya, fatwa yang diberikan dapat saja memunculkan respons negatif yang pada gilirannya akan menempatkan fatwa yang diumumkan hanya sebagai solusi hukum untuk sebagian orang yang bisa menempatkan kepentingannya di sana.

\section{PENUTUP}

Qiyas adalah warisan intelektual Islam yang original dan berharga. la hadir sebagai sebuah nalar islami yang didasari dari kesadaran dan kepekaan manusiawi dalam membaca dan memahami pesan-pesan shari'. Spirit ini membawa pada perkembangan dan pematangan metodologi qiyas cukup pesat dalam dinamika yang logis dan beradab.

Perkembangan metodologi qiyas yang secara umum dibagi ke dalam; (1) pemikiran hukum awal, dimana qiyas merupakan metode berfikir dalam mencari solusi hukum digunakan secara sederhana, dan
(2) pemikiran formal, yang berusaha memformulasi konsep qiyas menjadi metode penalaran yang terbatas dan ketat.

Pada masa awal, subjektifitas ahli menjadi penentu keputusan yang kemudian diumumkan/difatwakan serta diikuti oleh pengikut atau pengguna hukum. Meskipun tidak terlalu kebal terhadap kritik, format penalaran hukum awal lebih mempertimbangkan sisi maslahah. Sedangkan pada masa Al-Shafi'l dan selanjutnya, penalaran objektiftekstual adalah identitas utama, pengujian terhadap produk hukum yang dihasilkan dari penalaran qiyas bertumpu secara objektif terhadap teks/nash.

Dari pembacaan terhadap dinamika historis keberlakuan metodologi qiyas tersebut dapat diketahui pola penalaran hukum yang ada di organisasi-organisasi social keagamaan di Indonesia, di antaranya adalah MUI.

lembaga

tersebut

menggunakan qiyas sebagai salah satu metode penalaran hukumnya. Namunterdapat kelemahan dalam penggunaannya. Hal ini terjadi karena tidak ada usaha pemutakhiran metodologi yang berakibat pada penggunaan secara serampangan metode-metode yang dihasilkan para pemikir klasik, atau hanya sekedar menggabungkan sebagian dengan sebagian yang lain tanpa ada system verifikasi yang dapat memastikan validitas penggunaannya. 
Al-Fikra: Jurnal IImiah Keislaman, Vol. 16, No. 2, Juli - Desember, 2017 (332 353)

\begin{abstract}
Kenyataan ini mengisyaratkan akan adanya ketidak-pedulian kolektif akan penalaran-penalan logis hukum yang seyogyanya semakin matang dan kompleks karena ditangani oleh sekelompok orang dalam sebuah organisasi yang berijtihad secara kolektif, dibandingkan dengan yuris-yuris klasik yang nota bane bekerja sendiri.
\end{abstract}

\section{DAFTAR PUSTAKA}

Abd al-Karim bin Ali bin Muhammad al-Namlah, Ithaf dzawi alBashair bi Syarh Raudhat alNazhir fiUshul al-Fiqh 'ala Madzhab al-Imam Ahmad bin Hambal, Vol.7. Riyadh:Dar al'Ashimah, 1996.

Abdal-Azizal-Bukhari, KasyfalAsrar.Beirut:Daral-Fikr, 1927.

Abual-Walidibn Rusyd,Bidayat alMujtahid.Beirut:Daral-

Fikr,1997.

Abu Bakaral-Jashshash, Usul alJashshash. Kairo:Dar alKutub,tt.

Abu Bakaral-Sharakhsi, UsulalSharakhsi. Kairo: DaralKitabal-Arabi,1954.

Abu Husainal-Bashri, KitabalMu'tamadfî 'Ushul al-Fiqh. Beirut: Daral-kutubalIlmiyyah, 1982.

Ahmad al-Damanhuri, Syarh Idhah al-Mubham. Singapura: alHaramain, tanpa tahun.

Al-Bazdawi,Usul al-Bazdawi,dalam catatan pinggirKasyfal-Asrar. Beirut: Daral-Fikr,1927.
Amir Syarifuddin, UshulFiqh, jilid 1, Jakarta: Logos Wacana IImu, 1997.

Dewan Syari'ah Nasional MUI, Himpunan Fatwa Dewan Syari'ah Nasional.Ciputat: CV. Gaung Persada, 2006.

http://hizbuttahrir.or.id/2009/01/29/tanggap an-hizbut-tahrir-indonesiaterhadap-fatwa-mui-tentanggolput/. (di akses: Agustus 2015).

http://mui.or.id/mui/tentangmui/profil-mui/profil-mui.html (diakses pada Agustus 2015). http://www.hukumonline.com/berita/b aca/hol21080/komnas-hamkecam-fatwa-golput-haram. (diakses pada Agustus 2015).

Kamaluddin Abi Barakat ibn Anbari, luma' al-Adillah. Tt: tt, 1988.

Lexy J. Moleong, Metodologi Penelitian Kualitatif. Bandung: Rosdakarya, 1996.

Majelis Ulama Indonesia, Himpunan Fatwa MUI sejak 1975. Jakarta: Erlangga, 2011.

Mohammad Atho' Mudzhar, FatwaFatwa Majelis Ulama Indonesia; Sebuah Studi tentang Pemikiran Hukum Islam di Indonesia, 19751988.Terj. Soedarso Soekarno. Jakarta: INIS, 1993. Muhammad al-Syaukani, IrsyadalFuhulilaTahqiqal-Haqmin'ilmalUshul. Beirut: Daral-Fikr,tt.

Muhammad bin 'Abd al-Karim alSyahrastani, al-Milal wa alNihal, juz 3. Beirut: Dar alKutub al-'Ilmiyyah, 2007. 
Nasrullah; Majelis Ulama Indonesia (MUI); Studi Atas Penggunaan Metodologi Qiyas sebagai Upaya Penetapan Hukum Islam Di Indonesia

Muhammad bin Abi Sahl al-Sarhsi, Kitab al-Mabsuth, Juz.2. Beirut: Dar al-Fikr, tanpa tahun.

Muhammad bin Ahmad al-'Aini, AlBinayah fi Sharh al-Hidayah, juz 3. Beirut: Dar al-Fikr, 1990.

Muhammad bin Mahmud bin Ahmad al-Baberti Al-Hanafi, Al-Rudud wa Al-Nuqud; Syarh Mukhtashar Ibn al-Hajib, vol. 2. Riyadh: Maktabah al-Rusyd Nasyirun, 2005.

Muhammad Hasyim Kamali, The Principles of Islamic Jurisprudence, Cambridge: The Islamic Texts Society, 1991.

Robert bogdan, dkk, Pengantar Metoda Penelitan Kualitatif, terj. Arief Furqon. Surabaya: Usaha Nasional, 1992.

Said al-Afghani, Fi Ushul al-Nahwi. Beirut: Al-Maktab Al-Islami, 1987.

Saifuddin Abi Hasan al-Amidi, AlIhkam fiUshul al-Ahkam,juz 2. Beirut: Dar al-Fikr, 2003.

Struktur logika dalam teori hukum Islam (telaah atas teori qiyas dan double movement)" dalam www.scribd.com/doc/6173964 6/struktur-logika-dalam-teorihukum-islam. (diakses pada Agustus 2015)

Syafi'l, Muhammad bin Idris. alRisalah. Beirut:Dar al-Fikr, tanpa tahun.

Wahbah al-Zuhaili, Ushul al-Figh alIslami.Damaskus: Dar al-Fikr, 2005. 